This article was downloaded by: [University of Utah]

On: 06 August 2012, At: 09:01

Publisher: Routledge

Informa Ltd Registered in England and Wales Registered Number: 1072954 Registered office: Mortimer House, 37-41 Mortimer Street, London W1T 3J H, UK

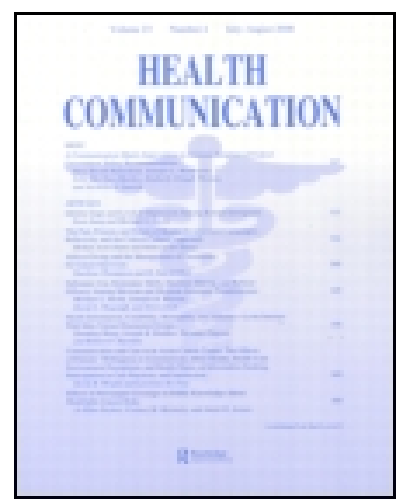

\title{
Health Communication
}

Publication details, including instructions for authors and subscription information: http:// www. tandfonline.com/loi/ hhth20

\section{HIV/AIDS in Botswana: President Festus G. Mogae's Narrative of Secular Conversion}

Robin E. J ensen ${ }^{a}$, Elizabeth A. Williams ${ }^{a}$, Isaac C. Holyoak ${ }^{b} \&$ Shavonne Shorter ${ }^{a}$

${ }^{a}$ Department of Communication, Purdue University

${ }^{\mathrm{b}}$ Department of Communication, Texas A\&M University

Version of record first published: 14 J un 2011

To cite this article: Robin E. J ensen, Elizabeth A. Williams, Isaac C. Holyoak \& Shavonne Shorter (2012): HIV/ AIDS in Botswana: President Festus G. Mogae's Narrative of Secular Conversion, Health Communication, 27:1, 19-29

To link to this article: http:// dx.doi.org/ 10.1080/ 10410236.2011.567448

\section{PLEASE SCROLL DOWN FOR ARTICLE}

Full terms and conditions of use: http://www.tandfonline.com/page/terms-and-conditions

This article may be used for research, teaching, and private study purposes. Any substantial or systematic reproduction, redistribution, reselling, loan, sub-licensing, systematic supply, or distribution in any form to anyone is expressly forbidden.

The publisher does not give any warranty express or implied or make any representation that the contents will be complete or accurate or up to date. The accuracy of any instructions, formulae, and drug doses should be independently verified with primary sources. The publisher shall not be liable for any loss, actions, claims, proceedings, demand, or costs or damages whatsoever or howsoever caused arising directly or indirectly in connection with or arising out of the use of this material. 


\title{
HIV/AIDS in Botswana: President Festus G. Mogae's Narrative of Secular Conversion
}

\author{
Robin E. Jensen and Elizabeth A. Williams \\ Department of Communication \\ Purdue University \\ Isaac C. Holyoak \\ Department of Communication \\ Texas A\&M University \\ Shavonne Shorter \\ Department of Communication \\ Purdue University
}

\begin{abstract}
Over the last decade, Botswana has been identified as a model for countries fighting against annihilation from HIV/AIDS. The country had the highest rate of HIV infections in the world in 2000, but by the end of Festus G. Mogae's presidential term in 2008 Botswana's situation had improved significantly, as residents were increasingly likely to get tested, obtain treatment, and discontinue practices of discrimination against the infected. This study seeks to contribute to a growing body of literature focusing on the communicative elements that played a role in Botswana's successes. More specifically, the purpose of this study is to explore Mogae's national speeches about HIV/AIDS to consider how his rhetoric may have encouraged Botswana's residents to alter their health-related beliefs and behaviors. We find that Mogae used a narrative of secular conversion (i.e., discourse with a pseudoreligious structure that positions problems as rooted in existing values and offers a new guiding principle as an antidote), and we identify such narratives as persuasive health communication tools. The analysis offers public health advocates, scholars, and opinion leaders a framework for persuasively communicating about diseases such as HIV/AIDS without drawing exclusively from a biomedical framework.
\end{abstract}

At the turn of the 21st century, Botswana was identified as the country with the highest rate of HIV infections in the world (UNAIDS, 2000). Botswana's then-President, Festus G. Mogae, warned residents and the international community that Botswana faced "extinction" without serious changes, not only in medical care and coverage but also in residents' beliefs, attitudes, and behaviors related to HIV/AIDS (Cohen, 2008, p. 527). With over 38\% of the population infected, approximately $40 \%$ of all pregnant

Correspondence should be addressed to Robin E. Jensen, Department of Communication, Purdue University, Beering Hall of Liberal Arts and Education, Room 2114, 100 N. University Street, West Lafayette, IN 47907-2098. E-mail: rejensen@ purdue.edu women testing HIV positive, and the average 15-year-old facing a 50\% chance of infection (Browne, 2007; Marlink \& Kotin, 2004), Mogae's assessment was hardly an exaggeration.

Yet by the time Mogae stepped down from presidential office in 2008, the country's prospects seemed much improved. Over 90,000 residents were receiving antiretroviral treatment (more than any other country in Sub-Saharan Africa), mother-to-child transmission rates were the lowest in Africa, population-level infection rates had dropped to approximately $24 \%$, and cultural norms of tolerance and support for the HIV-infected were steadily replacing norms of stigmatization and discrimination (Baputaki, 2009; Cohen, 2008; Furlonger, 2008). Today, although there is 
still important work yet to be done in the country's fight against HIV/AIDS, many scholars agree that Botswana's residents are notably healthier than they were one decade ago. To help explain and garner lessons from this transformation, researchers have explored different aspects of the medical infrastructure Mogae enacted during his presidency, focusing on opt-out testing policies (Creek et al., 2007; Kenyon, 2005), antiretroviral programs funded by publicprivate partnerships (Ramiah \& Reich, 2006), workplace HIV/AIDS educational efforts (Hope, 2003), and mother-tochild transmission prevention programs (Rakgoasi, 2005).

However, scholars have yet to explore how Mogae's rhetoric, in particular, may have helped to foster the cultural changes that transpired during his years in office, cultural changes that encouraged individuals to reconsider stereotypes and take advantage of the free prevention, testing, and treatment programs available to them. The lack of scholarship on Mogae's HIV/AIDS rhetoric is surprising because he has been repeatedly recognized as a national and international leader whose words have inspired change among individuals and mass publics alike (Dugger, 2008; Perry, 2008). Although it is impossible to measure exactly how much of Botswana's progress can be attributed to Mogae's rhetoric about HIV/AIDS, the consistently positive national coverage of his public discourse, as well as Mogae's commitment to speaking about HIV/AIDS in every speech he gave during his presidency (Zuckerbrod, 2008), provides compelling evidence that his speeches exhibited at least some degree of persuasive power and/or influence. In this study, we attempt to address this gap in knowledge by analyzing a sample of Mogae's national speeches during his presidential term, focusing specifically on speeches dedicated to the discussion of HIV/AIDS in Botswana. Our goal is to understand how Mogae persuasively communicated scientific information about HIV/AIDS to publics whose members were not likely to be persuaded solely by a biomedical framing. As Heald (2002) has pointed out, "the language of AIDS is the language of western science and policy" (p. 2). But this scientific discourse is not necessarily persuasive in situations where audience members are distrustful of or unfamiliar with scientific framing. In these cases, individuals are unlikely to register biomedical language as authentic and applicable to their lives (Petraglia, 2009). Thus, advocates must draw from a different discursive framework to convince community members to reconsider their beliefs, attitudes, and behaviors related to $\mathrm{HIV} / \mathrm{AIDS}$.

In this study, we argue that Mogae turned to an alternative framework known as a narrative of secular conversion: a communication strategy featuring a quasireligious discursive structure that endorses adoption of a new belief system and promises salvation from past problems (Branham, 1991; Burke, 1984). In the subsequent sections, we offer a review of literature on secular conversion narratives and a discussion about why such narratives have often been overlooked in scholarship on persuasion and behavior change. Then we present an analysis of Mogae's HIV-related national rhetoric during his presidential term, focusing specifically on his use of a secular conversion narrative to create a middle ground between biomedical and traditional beliefs about health and society. Finally, we consider secular conversion narratives as potential tools for opinion leaders working to inspire population-level behavior change.

\section{CHANGING BELIEFS ABOUT HIV/AIDS}

One of the fundamental questions in the field of health communication is how to encourage individuals and communities to abandon potentially injurious behaviors for behaviors deemed healthy by professional and scientific communities. Finding the answer to this question becomes especially complex when members of the communities in question have long adhered to a belief system (belief generally acting as an antecedent to corresponding behavior; Sheeran \& Abraham, 2001) that is at odds with medical recommendations. For instance, Botswana has long been the host of beliefs about the superiority of traditional healers and spiritualists (some of whom handle and ingest patients' blood as a healing tactic) to biomedical health professionals (Benedicte, 1990; Chipfakacha, 1997; Heald, 2002). Like many groups of individuals worldwide (Rintamaki, Davis, Skripkauskas, Bennett, \& Wolf, 2006; Smith \& Niedermyer, 2009), some Botswana residents also have a history of believing that HIV/AIDS is a sign of immorality or impurity and thus a condition to hide from others, thereby protecting the reputations of both the self and the family (Masland, 2001). Correspondingly, other prevalent beliefs have involved the idea that talk about sex is inappropriate and that it is normal and right for men to engage in extramarital and polygamous sexual relationships (Heald, 1995; Hope, 1995, 2001). Before Mogae's presidency, these beliefs - particularly those involving the stigmatization of individuals infected with HIV/AIDS — played a central role in keeping almost all residents from getting tested or identifying as HIV-positive. In 1997, only seven people in the country had "come out" as infected (Heald, 2006, p. 35). As Muturi (2005) found in her study of HIV-related knowledge and beliefs in rural Africa, inspiring belief change in cases such as Botswana's often requires that individuals forgo traditions, historical understandings of self and others, and well-ingrained loyalties in favor of unfamiliar ideas. Therefore, in the present study, we aim to identify and examine potential facilitators of such shifts in belief. We pose the following research question:

RQ1: How did Mogae persuasively communicate scientific information about HIV/AIDS to publics whose members were not likely to be persuaded solely by a biomedical framing? 


\section{Narratives of Secular Conversion}

Scholars of communication have long recognized the important role that narratives play in persuasive discourse. Not only has narrative and the process of storytelling been framed as a central element of human communication in general (Fisher, 1984; 1985); narrative discourse has also been distinguished as an organizing feature of much communication about health (Charon, 2009; Harter, Japp, \& Beck, 2005). Sharf and Vanderford (2003) argued that health narratives function to aid rhetors in making sense of and asserting control over their environments, laying out warrants for their claims, creating a sense of community, and building new identities for the self and others. Although all narratives work to satisfy these basic functions, scholars have identified different types of narratives with distinct features and emphases. For instance, cultural narratives focus on establishing a plot that is emblematic of what it means to be a member of a specific culture or nation (Olson, 2010; Rowland \& Jones, 2007), Exodus narratives focus on the process of leading others away-both physically and symbolically-from existing harms (Selby, 2008), and mobilizing narratives (Hart, 1992) function to create "collective identities for social movement organizations" (Miller, Martin, \& Beatty, 2005, p. 299).

In the present analysis, we focus on a specific subtype of the mobilizing narrative known as the narrative of secular conversion. Scholars have delineated narratives of secular conversion as central to inspiring belief-alteration among communities of individuals (Golden, Berquist, \& Coleman, 1984). Such narratives draw from the tone and structure of religious conversion rhetoric or "convert tales" to inspire dramatic shifts in secular belief (Branham, 1991, p. 407; see also Smith, 1999). Rhetors may incorporate religious terms and imagery into secular conversion narratives to build credibility for their claims and encourage audiences to consider their arguments in a sacred light (Jensen, 2005). Burke (1984) divided secular conversion rhetoric into two key components. First, he noted that secular conversion rhetoric is discourse that positions existing problems as rooted in past values. Fabj (1998) explained that, regardless of whether a conversion is secular or religious, it cannot occur unless an individual is willing to disassociate the self from the past and its order of rules. Thus, narratives designed to inspire conversion must begin by convincing audiences that the past has been guided by problematic values and that salvation from hardships depends on a break from the past.

Second, Burke (1984) explained that, unlike conversion rhetoric promoting or enacting an explicitly religious agenda (see, for example, Bailey, 2008), secular conversion rhetoric draws from religious symbolism, structures, and examples to further a secular cause (e.g., HIV/AIDS eradication and prevention). More specifically, secular conversion rhetoric offers up a new "god-term" (i.e., guiding principle or ideal organizing behavior) and vocabulary of values as an antidote for past and current problems (see also Burke, 1970, p. 2). According to Anderson (2007), a god-term functions to delineate a new scene of acceptable motives and actions. By adopting the proffered god-term and its accompanying vocabulary, individuals are positioned to "cast out demons" of the past and thereby disconnect themselves from their old injurious pieties and understandings of self (Burke, 1984, p. 133). In this way, narratives of secular conversion encourage individuals to "promise to adhere to the rules of the new order" (Fabj, 1998, p. 191).

Although scholars have recognized the potential discursive power of secular conversion narratives, for one key reason such narratives have been largely overlooked as tools for promoting societal-level behavior change: Secular conversion rhetoric is theorized as polarizing, offering no room for debate or middle ground. One is positioned as either adhering to the past and its problems, or as adhering to the healing guiding principles of the future (McGee, 1998). In this respect, such narratives have been framed as tools that serve to foster "intolerance" as much as to convert to new beliefs (Fabj, 1998, p. 200). In some cases, a dichotomous outlook on an issue may be appropriate. Jasinski (2001) provided the example of an ex-alcoholic who, in converting to sober living, rejected everything about the past that he connected with alcohol. In his new life, he avoided taverns, drunken friends, and rowdy social gatherings. The narrative of his conversion, and ultimately his sobriety, was grounded in this complete separation from the past. However, in other cases such as those requiring ongoing compromise and discussion among individuals representing differing opinions, advocates who endorse a complete break from the past will generally be dismissed by audiences as unrealistic and inflexible. In the subsequent analysis, we reconsider the claim that narratives of secular conversion are discursive tools that necessarily promote dichotomous reasoning, and we do so in light of President Mogae's national rhetoric about HIV/AIDS in Botswana. In this regard, we pose the following research question:

\footnotetext{
RQ2: How might a secular conversion narrative separate the past from the future while still endorsing a middle ground where the two coexist?
}

\section{METHOD}

\section{Critical Rhetoric Orientation}

Rhetorical methodologies tend to be especially useful for identifying and interpreting overarching discursive storylines and persuasive strategies. We drew from a critical rhetoric orientation to guide our selection of artifacts. Critical rhetoric procedures generally involve the identification of fragments of discourse, such as sections of speeches, interviews, and newspaper articles, and then the 
use of those fragments to build arguments about how discourse constructs and shapes communities' values, beliefs, and behaviors (McGee, 1990; McKerrow, 1989). In this way, the critical rhetoric orientation rejects the notion that texts are stable entities that individuals encounter uniformly from beginning to end. Instead, this approach works from the assumption that discursive fragments interact with each other to create meaning. Thus, rather than analyzing a single, self-contained text, the critical rhetorician considers multiple speeches, books, and/or other texts as representative of, and providing clues about, the larger discursive formations in which those fragments circulate. The goal for critical rhetoricians (and rhetorical scholars in general) is not to put forth objective, generalizable findings (Kline, 2007), but to offer a compilation of interrelated discursive fragments and to delineate emergent knowledge claims detailing how meaning seems to be created therein.

\section{Data Collection and Analysis}

The research team compiled a comprehensive list of Mogae's speeches from his years in presidential office (1998-2008). Then we located transcripts of the speeches (or newspaper coverage of speeches with no transcripts) via the African Presidential Archives and Research Center in Boston, MA, as well as online sources. We read through each speech systematically to assess content and develop criteria for inclusion in the study. Given our research interests, we decided on the following three criteria: (a) The speech was national (i.e., given in Botswana and explicitly speaking to Botswana's residents), (b) the speech focused primarily on the topic of HIV/AIDS in Botswana (i.e., the major argument throughout the speech was devoted to Botswana's response to HIV/AIDS), and (c) the speech was delivered exclusively by President Festus G. Mogae during his term in office. The resulting speeches that satisfied all criteria included Mogae's 2002, 2003, 2004, 2005, and 2007 addresses at Botswana's World AIDS Day Commemorations, and his 2005 Opening Remarks at the National HIV Prevention Conference, delivered in Francistown, Botswana. Mogae delivered all of his speeches in English. Thus, except for a few very short exceptions mentioned in the analysis, translation was not necessary.

After establishing the major artifacts (i.e., discursive fragments) for analysis, team members examined the resulting speeches for overall storyline and rhetorical appeals, supplementing their readings with international news coverage of Mogae's campaign against HIV/AIDS in Botswana as well as excerpts from Mogae's other communications during his time in office. After several phases of open and axial coding (Corbin \& Strauss, 2008), team members decided to focus on the speeches' narrative appeals and symbolic structures. We each wrote a variety of research memos throughout the analytic process, reading and commenting on each others' memos, and thereby building an audit trail of our interpretations (Lincoln \& Guba, 1985). During each stage of analysis, we identified and refined the research questions, which guided the final phases of our exploration. In the next section, we offer the results of our analysis.

\section{RESULTS}

Mogae's presidential rhetoric seemed designed to persuade Botswana's residents to change their beliefs about HIV/AIDS using a narrative of secular conversion that (a) identified the spread of disease as rooted in past values, (b) offered a new god-term and accompanying vocabulary as the antidote, and (c) created a middle ground between existing cultural expectations and new beliefs and behaviors.

\section{Problems Rooted in Past Values}

Although Mogae noted repeatedly in his speeches about $\mathrm{HIV} / \mathrm{AIDS}$ in Botswana that he wanted to focus on Botswana's future rather than its past, he nonetheless worked to establish the enormity of the country's problem, thereby inferring that a change in beliefs and behaviors was imperative. For instance, he began his 2002 World AIDS Day speech by lamenting, "It is with a heavy heart that I ruefully reflect that many of you may not recall a time when HIV and AIDS were not a primary threat to our personal lives and national livelihood" (p. 2). Beyond framing HIV/AIDS as an economic and material burden, in his keynote address at Botswana's National HIV Prevention Conference in 2005, Mogae recognized that the disease was also the source for much of the country's emotional pain by noting that "there is nothing pleasant about the task that has drawn us here today. The spread of the virus remains a constant source of sorrow," sorrow that the country and its residents could not continue to bear (p. 1).

To avoid framing Botswana's many HIV/AIDS-related losses as inevitable or irreversible, Mogae worked to position them as rooted in values of the past and therefore as something that could be overcome with a shift in values and accompanying beliefs and behaviors. More specifically, he framed the omnipresence of HIV/AIDS in Botswana as the result of widespread self-interest. By valuing the self above the nation and the health of its communities, Mogae argued that Botswana residents became disconnected from each other and increasingly likely to adopt, communicate, and act on what he labeled "the twin demons of stigma and discrimination" (2003, p. 4). For example, in his 2004 World AIDS Day speech, Mogae positioned one set of beliefs that perpetuated the spread of HIV/AIDS as rooted in men's self-interest in particular. He noted that men in Botswana had "come to be associated with actions that only serve to compound the problem. Issues of gender-based violence including murder, rape, incest, sexual abuse, and denial of 
reproductive health are perpetrated by men" (p. 6). Mogae reasoned that men who valued their own individual desires over the health and safety of others were contributing to the spread of HIV/AIDS and, in this way, were creating an unsafe, unhealthy environment for everyone, including themselves. Their self-interest ultimately worked against them (and others) and thus had to be replaced by another god-term.

Although Mogae more frequently blamed men and their self-interest for the perpetuation of HIV/AIDS, he argued that women's self-interested irresponsibility, while less insidious, was also contributing to the spread of the disease in Botswana. He noted that many women refused to be tested for HIV, rejected treatment after learning of a positive test result, and/or became pregnant after having unprotected sex "while knowing they were HIV positive" (2005b, p. 2). Mogae recognized that numerous women had little control over their sexual health as a result of the country's history of patriarchy and gender inequality. Indeed, Rothenberg and Paskey (1995) reported that African women have risked abuse and domestic violence for identifying themselves as HIV-positive and/or for trying to control their sexual interactions. Nonetheless, Mogae chastised women for bearing children under dangerous circumstances. He argued that women had to take an active role, both discursively and physically, in protecting their own health, the health of their children, and the health of their country. He recognized that "while individual circumstances may differ, the overall pattern is evidence that far too many [women] are failing to take responsibility for the welfare of themselves and others" (2005b, p. 2). Mogae did not use his speeches to outline steps women could take to avoid becoming infected or passing the infection on to their children, generally leaving those kinds of detailed messages for the country's many public health campaigns and treatment programs. Instead, he focused on building a case for the country's need to undergo a shift in values and, correspondingly, behaviors.

Mogae argued that the country's past problems with HIV/AIDS had to do not only with the self-interest of individual women and men, but also with the self-interest of entire family units and the drive within families to protect their reputations rather than expose members engaged in HIV/AIDS-conducive behaviors. For example, Mogae maintained that instances of "passion killings" (i.e., a "craze" that generally involved one member of a couple killing the other member and then committing suicide; Mberengwa, 2007, p. 35), incest, and child abuse demonstrated how entire families were often complicit in horrific sexual crimes and highlighted how unwillingness to talk about sex or to expose family members for sexual wrongdoings propagated the spread of HIV/AIDS (2007, p. 11). He argued:

In the recent past, we have witnessed an escalating wave of what has been termed "passion killings." The perpetration of these crimes is equally shared by both adults and youth. One is at a loss as to what has become of this nation-a nation that is acclaimed worldwide for peace and compassion. These killings are at the extreme end of the continuum. Other acts of violence against women and girls equally grave are domestic violence, incest, sexual defilement of minors, sexual coercion, and rape. (2004, p. 2).

Mogae associated this list of offenses with the past, however recent, and juxtaposed the past with the country's reputation for benevolence and democracy. Although publicly putting a stop to violent and incestuous behaviors might shame individual families, Mogae suggested that incest and molestation would be the end of the entire country if allowed to persist within families.

Mogae noted that sexual crimes and manipulation were also, more often than not, driven by economic exploitation and self-interest. He explained that "sugar daddy" and "sugar mummy" syndromes-in which one person pays or otherwise provides for another in exchange for a sexual relationship or interaction-had become rampant in Botswana and that "such immoral acts can only promote intergenerational and transactional sex, thus fueling the spread of HIV and AIDS" (2004, p. 3). Those taking advantage of economic power imbalances in this way were "angels of death," a phrase with religious connotations cuing audiences into Mogae's larger conversion appeals, as well as to the potentially fatal consequences of self-interest left unchecked (2004, p. 3). Being an angel of death could also be interpreted as one who is responsible for disrupting the natural order of life and death by engaging in evil or immoral activities. According to Mogae, only rampant self-interest could inspire a person to take advantage of others by paying them for sex, and only self-interest could foster "the spectre of stigma and discrimination" that kept individuals from speaking out against sexual abuse and manipulation, and from getting tested for HIV/AIDS and obtaining treatment (2002, p. 4). Once Mogae framed the HIV/AIDS "scourge" as directly related to men's, women's, and families' selfinterests $(2005 \mathrm{~b}$, p. 2), he turned to offering up a new overarching god-term (i.e., value) for the nation that would function to steer residents away from beliefs and behaviors that fostered disease.

\section{A New God-Term}

In his national speeches on HIV/AIDS in Botswana, Mogae separated the past and its guiding principle of self-interest from the nation's conversion to an emerging future, a future guided by a new god-term and an accompanying vocabulary of values. But before identifying the god-term of the future, Mogae found different ways to emphasize and celebrate the dramatic split that the nation was making from the past. For instance, he called for a break from "habit and routine," "a departure from the ordinary," and a refusal among the country's residents to "accept the status quo" 
(2002, pp. 3, 7). In this respect, Mogae framed the process of saving the country from extinction as intertwined with the development of new beliefs, habits, and behaviors among residents. He also claimed that he believed the country had "reached a crossroads in which there is genuine opportunity to begin to move towards significant and sustainable reduction in new HIV infections" (2005b, p. 2). The argument that opportunity (a word Mogae used repeatedly) can be gleaned from tragedy is common among secular conversion narratives and functions to inspire hope for what is to come (Burke, 1957). Throughout his national speeches on HIV/AIDS, Mogae emphasized his belief that "hope springs eternal from the human breast" in the face of tragedy-in this case the near extinction of the entire nation (2002, p. 2). And his crossroads analogy reiterated this optimism by positioning Botswana as capable of choosing a promising and prosperous future despite its seemingly bleak present situation.

The choice regarding which path the country should take, Mogae argued, was clear. The path of the past-paved with self-interest (i.e., the past/existing god-term) and a vocabulary emphasizing desire, fear, and power-would force residents to continue contemplating their country's annihilation. By contrast, the path of conversion-paved with a devotion to collective responsibility (i.e., the new god-term) and a vocabulary emphasizing collaboration, support, and dialogue-would guide the country toward a disease-free tomorrow. Certainly, Mogae noted, individuals had to take responsibility for their own actions to begin their journey on the latter path, but individual gains would be shortlived unless HIV/AIDS was situated within the context of a greater good and loyalty to others within the collective. Marking himself as a member of the collective (e.g., repeatedly using the pronouns "we" and "us"), Mogae contended, "We must support each other because we are in this struggle together" (2002, p. 6), and he noted that getting tested for HIV/AIDS constituted "a life-long commitment; a personal compact with oneself and the society you live with" (2007, p. 6). Mogae repeatedly emphasized the importance of vowing allegiance to Botswana by speaking of "the promises we must keep with others in order to survive" (2005a, p. 6). Just as some religious leaders take vows of chastity when they are ordained, Mogae inferred that Botswana residents would need to take vows of tolerance if they were to revitalize Botswana and its health. He argued that the questions guiding individuals had to change from those that focused on interest in the self to, "Where are our responsibilities as a community? Do we as a community look on unconcerned and dispassionately?" (2004, p. 4). Mogae insisted that accounting for the needs of all and finding "strength in numbers" was the principle that would direct Botswana toward salvation $(2002$, p. 2).

The new order depended not only on a vocabulary emphasizing collaboration and support, but also on, as Mogae put it, "asking questions and engaging in dialogue" (2002, p. 5).
The Botswana of the past had been operating under the notion that discourse about sex was inappropriate and unhealthy (Heald, 1995), but a Botswana driven by "our godgiven responsibility" to the collective would be devoted to "speak[ing] up openly about AIDS" (2004, pp. 3, 7) and being "frank in our discourse" (2005a, p. 2; 2005b, p. 1). If Botswana's residents remained convinced that talking about sex was wrong, Mogae maintained that they would never be able to assess the needs and HIV/AIDS-related problems of those around them. In this respect, any attempt to establish collective responsibility without also establishing a widespread willingness to discuss all topics potentially related to HIV/AIDS, would be unsuccessful. Mogae argued that even government leaders and employees had to become focused on engaging in open dialogue with "development partners, the private sector, nongovernmental sector and local communities" to "put together a comprehensive and coordinated national response" $(2004$, p. 6). This national response - the result of government dialogue and a citizenry discussing and debating HIV/AIDS-related issues-would contain and eventually eradicate the disease. Mogae claimed that the country and its residents could not remain silent and "passive, refusing unpleasant facts or prejudging our fellow countrymen [sic] who are infected by HIV" (2004, p. 7). A converted Botswana, according to Mogae, would depend upon communication among those representing all sectors of society. Such communication would fortify the collective and ultimately separate it from past problems.

But Mogae's collective inclusiveness was not without boundaries. In fact, he situated Botswana's problems within that of the international community only with the caveat that "ultimately the spread of the virus in Botswana is a challenge for Botswana. I therefore trust that this national gathering will focus on our own efforts" (2005b, p. 1). Mogae was clearly sympathetic to the plight of other countries dealing with HIV/AIDS as he was a frequent traveler, attending HIV/AIDS-related summits and conferences that he discussed in his national addresses upon his return. For example, in one case he noted that "I have today just returned from New York, where I participated in the United Nations' 60th Anniversary Summit and the launching of the Clinton Global Initiative," a program dedicated to creating international partnerships for the purpose of addressing HIV/AIDS and other worldwide problems (2005b, p. 1). He then went on to mention his trip to Rio de Janeiro for the International AIDS Society Conference and the many discussions he had there about HIV/AIDS as a global challenge. But, perhaps because Botswana had so recently been singled out as the country most severely affected by HIV/AIDS, he made it clear in his national speeches that he felt the country had to be guided by a sense of responsibility to its own residents above all else. Mogae likened the country and its residents to the biblical figure David who drew from his own "internal strength, [his] own ability to slay Goliath" (p. 4). David, much like the nation of Botswana, was seemingly at 
a disadvantage when he approached and eventually defeated his enemy. "Let us as Botswana," Mogae appealed, "discover our internal strength" and conquer HIV/AIDS "from within" (p. 1). Mogae suggested that a victorious Botswana depended upon individuals who felt intensely responsible for-almost religious about - their fellow residents and were invested in dedicating their existing resources to securing a collective victory.

Once Botswana had shown signs of developing a sense of collective responsibility regarding HIV/AIDS toward the end of Mogae's presidential term, Mogae turned more of his attention to helping the international community and argued that "the world must acknowledge that Botswana has a great deal to offer by way of lessons and best practices" $(2007$, p. 4). If other countries also converted to the principle of collective responsibility, Mogae reasoned that they too would break with their troubled past and defeat the virus "from within" (2005b, p. 1). But although Mogae focused his speeches on the importance of breaking with the past, he also signaled repeatedly that the conversion he was endorsing was one that could coexist with a number of Botswana's traditions and enduring cultural beliefs related to health and society.

\section{Creating a Middle Ground in Narratives of Secular Conversion}

Narratives of secular and religious conversion have been theorized as discourse that requires the rejection of one line of thinking in favor of total devotion to another perspective (McGee, 1998). However, Mogae's secular conversion rhetoric seemed to offer a counterpoint to this tenet. In his national speeches about HIV/AIDS, he encouraged audiences to reject values that manifested in the country's recent past while he also integrated emblems of the customary into advocacy for a future guided by collective responsibility. In the process, he seemed to offer audiences a middle ground where they could accept his claims without entirely disassociating from the national identity and beliefs that had characterized the country's sense of health and healing. For instance, he repeatedly pointed out what the country's "tradition" required in specific situations $(2007$, p. 4$)$, and he made a point of greeting his audiences in time-honored ways and explicitly drawing attention to audiences' expectations, saying, for instance, "Good afternoon. At gatherings such as this it is customary for the principal speaker to express how happy or pleased she or he is to be gracing the occasion" (2005b, p. 1). In this case, Mogae then departed from protocol, maintaining that "in all honesty, there is nothing pleasant about the task that has drawn us here today" (p. 1). By recognizing a protocol (even one that is relatively cross-cultural) before departing from its expectations, he legitimized existing understandings of social interactions without rejecting them permanently. In several of his speeches, Mogae further recognized and thus demonstrated respect for Botswana's historical identity with salutations that paired the English phrase "thank you" with the Setswana phrase "Pula," which means rain and thus blessings (2003, p. 8; 2004, p. 4). Both English and Setswana are the country's official languages, but those native to Botswana often learn to speak Setswana first (Levinson, 1998). Although there was a pragmatic dimension to Mogae's decision to feature a mixture of languages at key points in his addresses (this strategy helped to ensure that everyone understood Mogae's meaning, no matter their language), this rhetorical combination also had the additional benefit of offering audiences a sense that the past and the present could continue to peacefully coexist, even as residents altered their beliefs and behaviors related to public health.

One of the most telling examples in Mogae's rhetoric of his attempt to offer a secular conversion narrative with space for middle ground between the past and the future involved his statement that "there is a Setswana adage that says 'kgetsi ya tsie e kgonwa ke go tshwaraganelwa' " (2004, p. 7). Mogae did not translate this phrase for his audiences as he did in several other cases, thus signaling that his message was exclusively for those who were native residents of Botswana and reiterating his emphasis on responsibility to country above the international community. The phrase, roughly translated, means "teamwork bears more fruit than individual effort." In this case, Mogae was using Botswana's traditional language to communicate the new god-termcollective responsibility - that he believed characterized the country's future. Therein, he demonstrated that adopting this guiding principle did not mean that one had to also break from all things traditional or significant to the country's history. Mogae reiterated the continuity of the past to the future (rather than a complete break from the past) by making several appeals to the importance of passing on the legacy of Botswana to future generations. He drew from religious terminology by citing "the natural covenant that exists between generations," and assuring his constituents that "we are, ourselves, the legacies of those who came before us. As such we have a responsibility to ensure that through us the legacy of our ancestors is passed on to our own offspring" (2005b, p. 4). In this way, Mogae illustrated his own dedication to ensuring that Botswana's historical identity survived and framed his endorsement of biomedical discussions of HIV/AIDS as a means to that end.

Given that the means for achieving a greater good generally involves change and sacrifice, it probably came as no surprise to Mogae's audiences when he argued that certain viewpoints and healing methods could no longer be considered sufficient in diagnosing and treating HIV/AIDS. Mogae maintained that, "various homeopathic remedies, such as Canova, are not ARV [antiretrovirus] substitutes. They are, at best, only supplementary treatments" (2005b, p. 3). In this case, Mogae explicitly laid out his belief that treatments recognized by the biomedical community as effective such as antiretroviral drug therapies are superior to 
HIV treatments that are not widely endorsed by the Western medical community, such as homeopathic immune system enhancers. At the same time, however, he was also fostering the idea that the new order of HIV treatment and accompanying beliefs was flexible by labeling a therapy that was not included in Western standardized treatment as potentially supplementary, rather than harmful, and thus something to reject entirely. He reiterated this notion by saying, "In our efforts to prevent the spread of the virus we will, moreover, remain open-minded" (p. 3). Correspondingly, rather than endorsing biomedical views of HIV treatment carte blanche, Mogae questioned biomedical knowledge, thereby enacting a critical skepticism of information that he seemed to apply regardless of source or topic. In one instance, he noted that "it is claimed that male circumcision reduces the probability of HIV transmission from the female partner to the male by close to $60 \%$. It is in this regard that we are openminded about it, while exercising some caution" (2007, p. 10). Mogae's addresses illustrated that open-mindedness and caution are necessary when considering both old and new ideas, and, when used in combination with a dedication to collective responsibility, would allow those with and without HIV to carry "the national flag with pride and valor in their difficult journey of hope" (p. 8). In this way, the narrative of secular conversion that Mogae offered Botswana was one that allowed residents to retain links with the past while also looking forward to a day when prosperity and health reigned supreme.

\section{DISCUSSION AND IMPLICATIONS}

Over 31 million individuals worldwide are currently living with HIV/AIDS, and approximately 22 million of those individuals live in Sub-Saharan Africa, making it the most affected area in the world (UNAIDS, 2009). While Botswana in particular has made some important recent gains in the fight against HIV/AIDS, many neighboring countries are still facing possible annihilation. For example, South Africa now has the highest number of infections in the world, and Swaziland's rate of infection has been named the most severe with about $26 \%$ of adults infected (UNAIDS, 2009). HIV/AIDS has devastated these areas economically by drastically reducing the size of the workforce and socially by leaving thousands of children without parents or caregivers. Fortunately, in the midst of this devastation, Botswana's successes under Mogae's leadership function as a sign of hope and a potential model for other countries fighting an ongoing battle against HIV/AIDS. Although several factors distinguish Botswana from other African countries such as its relatively healthy economy from diamond mining (Cohen, 2008), many similarities exist such as its history of widespread HIV/AIDS stigmatization, dependence on traditional healers and spiritualists, and patriarchal social structure (Heald, 2002; Hope 2001).
Thus, scholarship that delineates variables that potentially contributed to Botswana's successes has implications for Sub-Saharan Africa and beyond.

In the present study, our first research question asked how the former President of Botswana, Festus G. Mogae, persuasively communicated scientific information about HIV/AIDS to publics whose members were not likely to be persuaded solely by a biomedical framing. We found that Mogae offered Botswana's residents a narrative of secular conversion concerning HIV/AIDS that framed the disease as rooted in past values and positioned the country's salvation as dependent upon its residents' conversion to a different guiding principle (i.e., god-term). More specifically, Mogae argued that self-interest and an accompanying vocabulary of desire, fear, and power had led the country to the brink of annihilation. Then he argued that residents who traded self-interest for collective responsibility and a vocabulary emphasizing collaboration, support, and dialogue could alter the country's trajectory. Mogae's national addresses about HIV/AIDS in Botswana did not function as public health messages outlining specific steps individuals could take to prevent and contain the disease, as he generally left such messages to the realm of public health campaigns, international addresses, and messages aimed at technical (rather than lay) audiences. Mogae addressed his citizenry in ways that furthered a national narrative about HIV/AIDS that depended very little on the language of biomedicine, drawing instead from pseudoreligious symbolism and rhetorical structure.

What made Mogae's secular conversion rhetoric theoretically different from similar narratives discussed in existing scholarship is that he created a discursive middle ground where elements of the old and the new could coexist. Branham (1991) argued that a key drawback of secular conversion rhetoric as a persuasive tool is that it tends to delegitimize "alternative viewpoints" and demand that adherents break completely from the past and all things connected to it (p. 421). From this perspective, the potential for such narratives to polarize community members limits their use as viable tools for opinion leaders and health advocates. Mogae's rhetoric, however, seemed to circumvent this drawback. He demonstrated how an opinion leader might narrate conversion to a new belief system while still respecting traditions, historical identities, and cultural expectations about health and society. More specifically, and in response to our second research question about how a secular conversion narrative might offer audiences discursive middle ground, we found that Mogae integrated time-honored phrases, ideas, and generational appeals into his narrative of conversion, thereby celebrating elements of Botswana's historical identity that did not correspond with potentially problematic (i.e., HIV/AIDS-related) values. In addition, he also advocated that residents consider all ideas related to disease management and treatment with an openminded skepticism, thus demonstrating that he was open 
to-and cautious of-biomedical and traditional therapies alike.

In this respect, the present study offers evidence that it is possible to create narratives of secular conversion that provide potential converts ways to combine the past with the future and promote dialogue rather than polarization. The case study at hand involved one rhetor's attempts to champion a mixed model of traditional and biomedical health. This rhetorical strategy ultimately seemed to help encourage Botswana residents to begin overcoming HIV/AIDS-related stigma and discrimination, which fostered increased testing and treatment. However, it should also be noted that Mogae's decision to step away from, or offer a tempered version of, the biomedical model of health communication may have had some negative implications. In focusing on bringing traditional understandings of society together with biomedical treatment for HIV/AIDS, Mogae focused less on HIV/AIDS prevention efforts championing monogamy and condom use, efforts that would require residents to renounce deeply ingrained beliefs about sexual agency and societal structures. Today, although there are fewer Botswana residents dying of HIV/AIDS and residents are now far more likely to know they have the disease if they are infected, the rates of new HIV/AIDS infections have decreased little since the beginning of Mogae's presidential term (Cohen, 2008). As the country reaches a new stage of development (i.e., safe from extinction but still struggling with high rates of HIV/AIDS infections), a new rhetorical framing or narrative is needed to guide residents toward long-term health and prosperity. Accordingly, after stepping down as President and becoming chairperson of Champions for an HIV-Free Generation, Mogae vowed to focus his discursive efforts more specifically on biomedically oriented prevention in Botswana (Powell, 2009). Although a secular conversion narrative may not serve as the rhetorical foundation for this stage of HIV/AIDS communication in Botswana, such efforts are made possible by the discursive ground that Mogae gained during his presidency via secular conversion narratives. Just as one model of health is often not enough to permanently sustain a community's vitality, one rhetorical framework or strategy is usually not enough to sustain a health communication effort for an extended period of time.

One important caveat when considering the results and analysis of the present study is that alternative god-terms for Botswana's past and future may have been at play in Mogae's addresses. For instance, beyond the principle of self-interest, it could be argued that Mogae framed the country's past as driven by conformity to existing norms, an unwillingness to change, or a sense of apathy about the future. Over the course of analyzing Mogae's national rhetoric about HIV/AIDS, we drew from existing methodological scholarship by McGee (1990), McKerrow (1989), and Corbin and Strauss (2008); and we concluded that the key organizing principle that guided Mogae's discussions about the past was self-interest, because he repeatedly juxtaposed residents' previous self-centeredness with their potential for developing a dedication to social responsibility. Future research on secular conversion narratives is needed to further clarify the methodological complications of identifying competing god-terms and interpreting accompanying pseudoreligious symbolism. In addition, future research exploring these findings in diverse contexts needs to continue shedding light on if, how, and why such discourse is persuasive. More specifically, research that explicates distinct types of secular and religious conversion narratives (i.e., polarizing; identity-building) by delineating their similarities and differences would provide increasingly detailed information for their application in health-related contexts.

Beyond HIV/AIDS and other sexually transmitted diseases, one health context that may be well suited for the application of secular conversion rhetoric-especially secular conversion rhetoric offering collective responsibility as a god-term-is that of vaccinations and population-level immunization campaigns. Despite biomedical support for the safety and efficacy of childhood vaccinations, a growing number of individuals in the United States and Europe have recently chosen not to get their children vaccinated, a phenomenon that has resulted in the reappearance of previously eradicated diseases (Ratzan, 2010). Opinion-leader discourse structured as a narrative of secular conversion may have the potential to help transform individualistic, antivaccination values into collectively oriented provaccination ideals. As a subtype of the mobilizing genre of narrative communication (Miller, Martin, \& Beatty, 2005), secular conversion narratives have the unique capacity to inspire seemingly disconnected individuals to see themselves as united under a single cause. The pseudoreligious symbolism and imagery woven throughout such narratives grant the issue at hand an added degree of significance and familiarity among many audiences. Thus, what may have originally appeared an inconsequential decision made by individuals (e.g., getting tested for HIV/AIDS; agreeing to have one's children vaccinated) is transformed into a symbol of social identity and thus worthy of extended consideration and adherence. The present study's finding that secular conversion narratives can promote compromise rather than polarization positions such narratives as rhetorical tools for bringing people together and altering community-level beliefs and behaviors. In this respect, Mogae's rhetoric offers discursive lessons with the potential for widespread and successful application in countless health-related contexts.

\section{REFERENCES}

Anderson, D. (2007). Identity's strategy: Rhetorical selves in conversion. Columbia: University of South Carolina Press.

Bailey, D. C. (2008). Enacting transformation: George W. Bush and the Pauline conversion narrative in A Charge to Keep. Rhetoric \& Public Affairs, 11, 215-242. 
Baputaki, C. (2009, July 28). Mother-to-child HIV transmission lowest in Africa-Study. Mmegionline, 26. Available at: http://www.mmegi.bw/ index.php?sid=1\&aid=32\&dir=2009/July/Tuesday 28

Benedicte, I. (1990). The cultural construction of AIDS and its consequences for prevention in Botswana. Medical Anthropology Quarterly, 4, 28-40.

Branham, R. J. (1991). The role of the convert in Eclipse of Reason and The Silent Scream. Quarterly Journal of Speech, 77, 407-426.

Browne, P. (2007). The best of times, the worst of times. Griffith Review, 17, 1-9.

Burke, K. (1957). The philosophy of literary form: Studies in symbolic action (rev. ed.). New York: Vintage.

Burke, K. (1970). The rhetoric of religion: Studies in logology (2nd ed.). Berkeley: University of California Press.

Burke, K. (1984). Permanence and change: An anatomy of purpose (3rd ed.). Berkeley: University of California Press.

Charon, R. (2009). Narrative medicine as witness for the self-telling body. Journal of Applied Communication Research, 37, 118-131.

Chipfakacha, V. G. (1997). STD/HIV/AIDS knowledge, beliefs and practices of traditional healers in Botswana. AIDS Care, 9, 417-425.

Creek, T. L., Ntumy, R., Seipone, K., Smith, M., Mogodi, M., Smit, M., . . . Kilmarx, P. H. (2007). Successful introduction of routine opt-out HIV testing in antenatal care in Botswana. Epidemiology and Social Science, 45, 102-107.

Cohen, J. (2008, July 25). Botswana's success comes at steep cost. Science, 321, 526-529.

Corbin, J., \& Strauss, A. (2008). Basics of qualitative research $3 e$. Thousand Oaks, CA: Sage.

Dugger, C. (2008, October 21). Botswana's ex-president wins leadership prize. New York Times, p. A8.

Fabj, V. (1998). Intolerance, forgiveness, and promise in the rhetoric of conversion: Italian women defy the Mafia. Quarterly Journal of Speech, 84, 190-208.

Fisher, W. R. (1984). Narration as human communication paradigm: The case of public moral argument. Communication Monographs, 51, 1-22.

Fisher, W. R. (1985). The narrative paradigm: An elaboration. Communication Monographs, 52, 347-367.

Furlonger, D. (2008, April 11). Botswana: Changing of the guard. Financial Mail, p. 46.

Golden, J. L., Berquist, G. F., \& Coleman, W. E. (1984). Secular and religious conversion. In The rhetoric of Western thought (4th ed., pp. 152-163). Dubuque, IA: Kendall-Hunt.

Hart, J. (1992). Cracking the code: Narrative and political mobilization in the Greek Resistance. Social Science History, 16, 631-668.

Harter, L. M., Japp, P. M., \& Beck, C. S. (2005). Vital problematics of narrative theorizing about health and healing. In L. M. Harter, P. M. Japp, \& C. S. Beck (Eds.), Narratives, health, and healing: Communication theory, research, and practice (pp. 7-29). Mahwah, NJ: Lawrence Erlbaum Associates.

Heald, S. (1995). The power of sex: Reflections on the Caldwells' "African Sexuality" thesis. Africa, 65, 489-505.

Heald, S. (2002). It's never as easy as ABC: Understandings of AIDS in Botswana. African Journal of AIDS Research, 1, 1-10.

Heald, S. (2006). Abstain or die: The development of HIV/AIDS policy in Botswana. Journal of Biosocial Science, 38, 29-42.

Hope, K. R. (1995). The socio-economic context of AIDS in Africa. Journal of Developing Societies, 11, 179-188.

Hope, K. R. (2001). Population mobility and multi-partner sex in Botswana: Implications for the spread of HIV/AIDS. African Journal of Reproductive Health, 5, 73-83.

Hope, K. R. (2003). Promoting behavior change in Botswana: An assessment of the peer education HIV/AIDS prevention program at the workplace. Journal of Health Communication, 8, 267-281.

Jasinski, J. (2001). Sourcebook on rhetoric: Key concepts in contemporary rhetorical studies. Thousand Oaks, CA: Sage.

Jensen, R. E. (2005). The eating disordered lifestyle: Imagetexts and the performance of similitude. Argumentation and Advocacy, 42, $1-18$.
Kenyon, K. (2005). Routine HIV testing: A view from Botswana. Health and Human Rights, 8, 21-23.

Kline, K. N. (2007). Cultural sensitivity and health promotion: Assessing breast cancer education pamphlets designed for African American women. Health Communication, 21, 85-96.

Levinson, D. (1998). Ethnic groups worldwide. Phoenix, AZ: Oryx Press.

Lincoln, Y., \& Guba, E. (1985). Naturalistic inquiry. Beverly Hills, CA: Sage.

Marlink, R. G., \& Kotin, A. G. (2004). Global AIDS crisis: A reference handbook. Santa Barbara, CA: ABC CLIO.

Masland, T. (2001, June 11). Botswana's hope: This tiny African nation is leading the war against the AIDS pandemic. Newsweek. Available at: http://www.newsweek.com/id/79033

Mberengwa, L. R. (2007). Family strengths perspectives from Botswana. Marriage and Family Review, 41, 27-46.

McGee, B. R. (1998). Witnessing and ethos: The evangelical conversion of David Duke. Western Journal of Communication, 62, 217-243.

McGee, M. C. (1990). Text, context, and the fragmentation of contemporary culture. Western Journal of Speech Communication, 54, 274-289.

McKerrow, R. E. (1989). Critical rhetoric: Theory and praxis. Communication Monographs, 56, 91-111.

Miller, M. Z., Geist-Martin, P., \& Beatty, K. C. (2005). Wholeness in a breaking world: Narratives as sustenance for peace. In L. M. Harter, P. M. Japp \& C. S. Beck (Eds.), Narratives, health, and healing: Communication theory, research, and practice (pp. 295-310). Mahwah, NJ: Lawrence Erlbaum Associates.

Mogae, F. G. (2002, December 1). On World AIDS Day. Statement presented at the 2002 World AIDS Day Commemoration, Gaborone, Botswana. Available at: http://www.bidpa.bw/docs/archive/ WORLDAIDSDAYSPEECH2002.pdf (accessed September 1, 2009).

Mogae, F. G. (2003, December 1). Commemoration of World AIDS Day. Statement presented at the 2003 World AIDS Day Commemoration, Francistown, Botswana. Available at: http://www.naca.gov.bw/sites/ www.naca.gov.bw/files/speeches/World\%20AIDS\%20Day\%20Commemeoration\%20December\%201\%202003\%20Francstown.pdf (accessed December 10, 2010).

Mogae, F. G. (2004, December 1). Keynote address. Statement presented at the 2004 World AIDS Day Commemoration, Ghanzi, Botswana. Available at: http://www.naca.gov.bw/sites/www.naca.gov.bw/files/ speeches/World\%20AIDS\%20Day\%20December\%201\%20Gantsi\%20 2004.pdf (accessed September 1, 2009).

Mogae, F. G. (2005a, December 1). At the commemoration of the 2005 World AIDS Day. Statement presented at the 2005 World AIDS Day Commemoration, Letlakane, Botswana. Available at: http://www. naca.gov.bw/sites/www.naca.gov.bw/files/speeches/World\%20AIDS\% 20Day $\% 20$ Commemoration $\% 20$ December\%201\%20Letlhakane $\% 20$ 2005\%20.pdf (accessed December 10, 2010).

Mogae, F. G. (2005b, September 9). Opening remarks at the National HIV Prevention Conference. Statement presented at the National HIV Prevention Conference, Francistown, Botswana. Available at: http:// www.naca.gov.bw/sites/www.naca.gov.bw/files/speeches/National\%20Prevention\%20Conference\%20Francistown\%20Speech.pdf (accessed September 1, 2009).

Mogae, F. G. (2007, December 1). World AIDS Day Commemoration. Statement presented at the 2007 World AIDS Day Commemoration, Letlhakeng, Botswana. Available at: http://www.naca.gov.bw/sites/ www.naca.gov.bw/files/speeches/World\%20AIDS\%20Day\%20Commemoration\%20December\%201\%20Letlhakeng\%202007.pdf (accessed December 10, 2010).

Muturi, N. W. (2005). Communication for HIV/AIDS prevention in Kenya: Social-cultural considerations. Journal of Health Communication, 10, 77-98.

Olson, C. J. (2010). Performing embodiable topoi: Strategic indigeneity and the incorporation of Ecuadorian national identity. Quarterly Journal of Speech, 96, 300-323.

Perry, A. (2008, October 20). Festus Mogae: Africa's good leader. Time. Available at: http://www.time.com/time/world/article/0,8599,1852066, 00.html (accessed September 28, 2010). 
Petraglia, J. (2009). The importance of being authentic: Persuasion, narration, and dialogue in health communication and education. Health Communication, 24, 176-185.

Powell, A. (2009, April 16). Mogae shifts stress to HIV prevention. Harvard Gazette. Available at: http://news.harvard.edu/gazette/story/ 2009/04/mogae-shifts-stress-to-hiv-prevention (accessed December 1, 2009).

Rakgoasi, S. D. (2005). HIV counseling and testing of pregnant women attending antenatal clinics in Botswana, 2001. Journal of Health, Population and Nutrition, 23, 58-65.

Ramiah, L., \& Reich, M. (2006). Building effective public-private partnerships: Experiences and lessons from the African Comprehensive HIV/AIDS Partnerships (ACHAP). Social Science and Medicine, 63, 397-408.

Ratzan, S. C. (2010). Setting the record straight: Vaccines, Autism, and the Lancet. Journal of Health Communication, 15, 237-239.

Rintamaki, L. S., Davis, T. C., Skripkauskas, S., Bennett, C. L., \& Wolf, M. S. (2006). Social stigma concerns and HIV medication adherence. AIDS Patient Care and STDs, 20, 359-368.

Rothenberg, K. H., \& Paskey, S. J. (1995). The risk of domestic violence and women with HIV infection: Implications for partner notification, public policy, and the law. American Journal of Public Health, 85, 1569-1576.

Rowland, R. C., \& Jones, J. M. (2007). Recasting the American Dream and American politics: Barack Obama's keynote address to the 2004
Democratic National Convention. Quarterly Journal of Speech, 93, 425-448.

Selby, G. S. (2008). Martin Luther King and the rhetoric of freedom: The Exodus narrative in America's struggle for civil rights. Waco, TX: Baylor University Press.

Sharf, B. F., \& Vandeford, M. L. (2003). Illness narratives and the social construction of health. In T. L. Thompson, A. Dorsey, K. I. Miller \& R. Parrott (Eds.), Handbook of health communication (pp. 9-34). Mahwah, NJ: Lawrence Erlbaum Associates.

Sheeran, P., \& Abraham, C. (2001). The health belief model. In M. Conner \& P. Norman (Eds.), Predicting health behavior: Research and practice with social cognition models (pp. 23-61). Philadelphia: Open University Press.

Smith, K. K. (1999). The dominion of voice: Riot, reason, and romance in antebellum America. Lawrence: University Press of Kansas.

Smith, R. A., \& Niedermyer, A. J. (2009). Keepers of the secret: Desires to conceal a family member's HIV-positive status in Namibia, Africa. Health Communication, 24, 459-472.

UNAIDS. (2000). Report on the global HIV/AIDS epidemic: June 2000. Geneva: UNAIDS/WHO

UNAIDS. (2009). AIDS epidemic update 2009. Geneva: UNAIDS/WHO.

Zuckerbrod, N. (2008, October 20). African leader in AIDS fight wins $\$ 5$ million prize. USA Today. Available at: http://www.usatoday.com/ news/world/2008-10-20-503107833_x.htm (accessed September 28, 2010). 